\title{
LEGAL STATUS OF THE EAST AFRICAN COMMUNITY (EAC)
}

\author{
Lily N. Njenga \\ Peoples`Friendship University of Russia \\ Law Institute \\ Mikluho-Maklaya, 6, Moscow, Russia, 117198
}

The history of the "metamorphosis" of the East African Community (hereafter the EAC), though for the period of over a decade, is not so different from other international regional organizations. For example, the European Economic Community (hereafter the EEC) also underwent some 'transformation' before eventually becoming the $\mathrm{EU}^{1}$. More particularly, the article reflects on the early stages of the formation of the EAC, its early challenges and how it may have overcome them to attain its present status. Further, the article reflects on the roles and functions of the East African Community organs and institutions and at the same time touch on the important documents as legal instruments that have been adopted and ratified by the partner states. Additionally, the article will reflect on how effective the EAC has been in its commitment to observe the principles of democracy, the rule of law and social justice so as to show that the EAC stands out from other regional economic organizations in the continent. In conclusion this article will show that the history of the existence of the EAC and its reestablishment in 2000, give grounds to embrace its legal status especially following one of their objectives to form a federation among other principles listed in the treaty, which are in line with the general principles of International law.

Key words: East African Community (EAC), Regional economic communities (REC), Treaty, formation, history, integration

\section{INTRODUCTION}

The history of the co-operation in East African region can be traced to as early as the era of "The East Africa common market" which dates back to the late $19^{\text {th }}$ century and early $20^{\text {th }}$ century. It is evident that even before any of these member states gained independence, there existed a common idea of how East Africans would form a centralized governing system that would incorporate all tribes and cultures for the common good of all (Whitaker, 1964: 84). The EAC undoubtedly has a history that developed in stages in the stretch of a century. African regionalism is described in a publication by Ally Possi to have three phrases: Pre-independence phase, postindependence phase and new millennium phase (Possi, 2013:173-195). In the pre-

\footnotetext{
${ }^{1}$ By virtue of the Rome treaty in 1957 was formed for the main purpose of economic integration among its member states. The EEC was in 1993 incorporated into the European Community and was later absorbed into the European Union.
} 
independence phase, the East African High Commission governed the three territories. It had its own structure and oversaw the common market activities as well as legislative matters. In the post-independence phase the East African High Commission was replaced by the East African Common Services Organization ${ }^{2}$.

The new millennium phase is the culmination of the re-establishment of the EAC up to date. It is inevitable not to discuss about the EAC as an international organization by looking at its structure which includes the organs and institutions that have been established under the treaty, the goals and general principles under which it fulfills its obligations in accordance with the Treaty and in the concept of international law. The legal background of the EAC will be reflected also with some attention given to the key documents that have been signed. These documents include treaties, protocols, acts and other documents that are considered legally binding by and among the member states. In general, the EAC as a regional economic community has been under the keen study of historians, philosophers, lawyers, political scientists and Economists both from Soviet Union, Russia and abroad such as Abashidze, Solntsev, Adou, Tuzmuhamedov, Potemkin, Kuznetsova, Polkovnikova, Hazel Woods, Stefan Reith, Ritz Boltz, James Gathii, Peter Draper, Ally Possi, Laurence Helfer just to name a few. Some of their work and findings will be mentioned in this article.

\section{THE HISTORICAL BACKRGOUND OF THE EAC}

The idea of integration in East Africa and more specifically the establishment of the East African Empire stretches back to the late XVII century during the time of the first Emissary to England F. Lugard. At that time the Secretary for the Colonies in England said that he could foresee the day when a great federation of Eastern Africa will come to existence. To have complete control over their colonies and the activities, the English imperialists had to create a central force to strengthen its economic and political domination. This was not a difficult task because the three East African Territories had been of keen interest as an object of integration policy to the British imperialists for over a century. This is what gives EAC a unique feature hence making it the most economically connected REC in Africa. There wasn't a developed official system for the territories of the common agreements that had existed before 1926. But throughout the 1920s the subject was under open active discussion especially in relation to creating a more legally binding cooperation, and particularly forming a federation of the East African territories.

\footnotetext{
${ }^{2}$ Following the attainment of Independence of Tanganyka, the East African High Commission was replaced by the East African Common Services Organization (E.A.S.C.0.) which was to continue the general administration of the several services in the three territories on an East African basis. The signatories were Julius K. Nyerere Prime Minister of Tanganyika; Patrick Renison Governor of Kenya and Ronald G. Ngala, as Leader of the House in Kenya; and W. F. Coutts Governor of Uganda and K. B. M. Kiwanuka who was Chief Minister of Uganda.
} 
The underlying discussion was "divided" among those who favored the settlers and saw the need for a closer cooperation of the territories on the presumption that this would be a prerequisite on relaxing the grip that the British had on the colonies, while those who expressed their concern to safeguard interests of the Africans feared that a closer association between the territories would give leverage to Whitehall who would end up dominating key positions ${ }^{3}$. To this effect a commission was delegated, which concluded that forming a federation was unwelcome for practical reasons ${ }^{4}$. In a joint article, Stefan Reith, ${ }^{5}$ and Moritz Boltz, ${ }^{6}$ point out that the initial steps towards "cooperation between the states were made in 1919" (Reith, Boltz, 2011). This is the time when Kenya, Tanganyika and Uganda - all of them under British administration - formed a customs union. Although Uganda and Kenya had initially agreed on the union by 1917, Tanganyika had a differing point of view that can be considered as one of the turning points for future compatibility issues.

The opening of the Uganda Railway saw traffic of imports to Uganda from Mombasa port heighten at the expense of imports from the port of Tanganyika. As a result, a first attempt to settle this revenue collection was made in 1909. An arrangement was also agreed upon between Kenya and Uganda for free trade in locally made products and in imported goods. The provisions of free trade in local produce and in imported goods between Kenya and Uganda were outlined in the agreement establishing the common customs administration to ensure a common external tariff existed between the two territories; It was hence assumed that there was a single customs administration for the two territories of Kenya and Uganda. Tanganyika was not brought fully into the union for another ten years. The establishment of the East African Currency Board at the end of 1919 saw the introduction of a common currency in the three territories.

By 1923, free trade between Kenya Uganda and Tanganyika had picked up. It was not until 1925 that the board completed the conversion process and the East African shilling was introduced for use in the three territories. The founding of the East African High Commission in 1948 resulted in the strengthening of the economic ties between these territories. Given the historical fact that East Africa jurisdictions were drafted by British civil servants who had a common social and educational background and tended to consult with counterpart officials in other colonies, and who

\footnotetext{
${ }^{3}$ The major state media papers covered this debate between 1924 and 1931.

${ }^{4}$ There existed several unresolved issues between the states in their cooperation for example Uganda expressed injustice by Kenya over customs matters. The major problem had been resolved albeit the introduction of reallocation in 1909. Some of the major steps taken to try and resolve these misunderstanding included the principle of derivation introduced in 1923 and improvement of the administration in 1927.

${ }^{5}$ At the time, was Resident Representative of the Konrad-Adenauer-Stifung in Tanzania.

${ }^{6}$ At the time, Moritz Boltz was studying politics, economics and law at Ludwig Maximilian University in Munich. He was based at the KAS office in Tanzania for three months while he researched the East African Community.
} 
were often advised about the content of legal frames by the central Colonial Office in London that was charged with administering all the British colonies, it is not surprising then that there exists basic similarity of most laws concerning trade among the partner states, moreover, there have been recurrent efforts to achieve even greater uniformity in the past few decades.

The establishment of The East African High Commission was the colonialists' way of governing the region with intentions to possess absolute power especially to legislate trade in the East African region. This commission also became the basis for a supposedly strengthened customs union and a unified income tax. The next major step in pursuit of regional integration in the region is when The East African High Commission which functioned during the colonial era was succeeded by The East African Common Service Organization (hereinafter the EACSO) following the end of the colonial period.

It is within this year that the region saw great legal and political changes that would shape East Africa in the future. After Kenya obtained full internal selfgovernment, the heads of the other two independent East African territories jointly pledged to work together towards the formation of an East African Federation ${ }^{7}$. Pursuant to this declaration, the heads of states formed a committee that consisted of ministers from each of the three countries to work on the details of a constitution for the proposed formation of a federation. Tanganyika called upon the new leaders to concentrate on economic co-operation as opposed to political (Sebalu, 1972: 345-363). Important meetings were held under the East African Common Services Organization. These meetings facilitated appointments and restructuring of the organizations administration including the appointment of a new president of the Court of Appeal for Eastern Africa Sir Samuel Quashie-Idun following the retirement of the previous president Sir Ronald Sinclair who was from the British colonial government. During this period, the Central Legislative Assembly of the three countries amended some acts including the East African Customs Management Act and The East Africa Excise Management Amendment Act. Additionally, stronger measures for the control of licensing of radio communication stations and apparatus were introduced in accordance with The East African Posts and Telecommunications Amendment Act of 1963.

Many other acts were amended for example The Appropriation (1962/1963) Non-Self - Contained Services Act, The East African Airways Corporation Act 1963. The commitment within all the agreements signed by the three states between 1963 and 1967 promoted free and flexible movement of goods, capital and labor. The goals and objectives set forth were in the heart of common efforts which were supposed to lead the three member states, into concluding an agreement to launch a common market for the three East African states.

\footnotetext{
${ }^{7}$ The East African Common Services Organization. Annual Report. 1963. P. 1.
} 
A second attempt to establish a regional integration in East Africa was made in 1967 when the East African Corporation ${ }^{8}$ was created ${ }^{9}$. The treaty for East African Co-operation of 1967 replaced the East Africa High Commission and the East African Common Services Organisation. The aim of which, was to control and administer matters of common interest and to regulate the commercial and industrial relations and transactions between the said countries by means of a central legislature. This new legislative body was to enact laws relevant to the objectives of the said joint organization $^{10}$. To this effect and in accordance with articles $30,31,46,47,48,49,50$, 51, 53(a), 53(b),53(c), 53(d), 54, 55, 56, 57, 58, 59, 60 of the 1967 Treaty for East African Co-operation, several key institutions that would play a vital role in the future of the EAC, were established. Some of these institutions include the East African Legislative Assembly and Ministers of the Community. Other Important achievements of this treaty include the establishment of judicial bodies ${ }^{11}$ and other specialized departments $^{12}$.

However, despite all the hard work and activities of the member states of the EAC Cooperation, the Treaty for East African Cooperation was officially dissolved in 1977 owing to various reasons including the continued disproportionate sharing of benefits of the Community among the Partner States due to "their differences in their levels of development" and the fact that each country was struggling to find their way into the system of governing by the former colonialists who had not entirely loosened their grip. However, after the collapse, the three East African countries did not 'throw in the towel' but instead continued to seek avenues to re unite and by so doing signed a mediation agreement (herein after - the Mediation Agreement) for the division of assets and liabilities of the former East African Cooperation on $14^{\text {th }}$ of May 1984 in Arusha, Tanzania ${ }^{13}$.

\footnotetext{
${ }^{8}$ Commonwealth Heads of Government and States (CHOGS) Held on November 1991.

${ }^{9}$ The treaty for the cooperation of the East African Community was signed in 1967.The three member states Kenya, Uganda and Tanzania aimed at a common customs tariff and various common public services including a joint syllabus and thus an East African examination body.

${ }^{10}$ Preamble of the EAC Treaty.

${ }^{11}$ EAC Treaty. Article 80-81.

${ }^{12}$ East African Community, The East African Community; A Handbook 1972 // Arusha, East African Community Information Division, 1970. The bodies and institutions included the Meteorological Department, the Freshwater Fisheries Organisation, the Industrial Research Organisation, the Institute of Malaria and Vector-Borne Diseases, the Institute for Medical Research, the Leprosy Research Institute, the Marine Fisheries Research Organisation, the Pesticides Research Organisation, the Agriculture and Forestry Research Organisation, the Trypanosomiasis Research Organisation, the Tuberculosis Investigation Centre, the Veterinary Research Organisation and the Virus Research Institute.

${ }^{13}$ The East African Community Mediation Agreement signed in 1984. The three states agreed to divide the assets and liabilities of the former East African Community as well to explore and identify areas for future cooperation.
} 
Based on this agreement under Article 14.02, the three heads of states convened in a summit held in Harare, Zimbabwe and agreed to explore and identify areas for future co-operation announcing their intention to re-launch the EAC. The future of the East African Cooperation was uncertain but it did not succumb to slumber. After almost ten years, because of subsequent meetings, the Republic of Kenya, the Republic of Uganda and the United Republic of Tanzania on 30 November 1993 established a Permanent Tripartite Commission hereinafter referred to as (the Tripartite Commission). The Tripartite Commission was put in place to oversee not only economic but also social, political, cultural and security matters in the region. This commission was the brainchild towards binding the three states to a legal commitment in fulfilling their common objectives for cooperation. An approval for the East African Development strategy for the period 1997-2000 by the heads of states in Arusha, Tanzania on $29^{\text {th }}$ April 1997 created a path for serious negotiations to upgrade the Agreement establishing the Tripartite Commission into a treaty. As a result, the new Treaty for the establishment of the EAC was signed on $20^{\text {th }}$ November 1999 during the $4^{\text {th }}$ summit of the heads of State by the three initial member states. The main goals of this treaty were to mark a re-birth of the EAC whose main focus included establishing not only a common market but consequently a federation with a common currency ${ }^{14}$.

In the modern context of restructuring of the EAC, the three states continued to seek new paths for strengthening cooperation in the region.

\section{THE EAC AS AN INTERNATIONAL ORGANISATION}

The EAC, as defined by Amerasinghe, is "an inter-governmental, supranational and closed organization" that seeks to widen and deepen integration with the systematic establishment of a Customs Union, a Common Market, a Monetary Union and ultimately a Political Federation ${ }^{15}$. It also emphasizes strong participation of the private sector and civil society in its co-operation programmes and activities ${ }^{16}$. The EAC was established as a community by the EAC Treaty of $1999^{17}$. The EAC is a regional intergovernmental organization that is made up of six member States namely the Republic of Kenya, the United Republic of Tanzania, the Republic of Uganda, the Republic of Rwanda, the Republic of Burundi ${ }^{18}$ and the Republic of South Sudan ${ }^{19}$. The EAC Treaty entered into force in July 2000 after being ratified by the three initial member states. It is important to note that the capacity of the EAC as an international intergovernmental organization may not be clearly reflected, that is expressis verbis

\footnotetext{
${ }^{14}$ EAC Treaty. Article 2 (2).

15 Ibid. Articles 2, 5.

${ }^{16}$ Ibid. Articles 5 (3)(g), 127-129.

${ }^{17}$ Ibid. Article 2 (1).

${ }^{18}$ Rwanda and Burundi both joined the EAC in July 2007.

${ }^{19}$ South Sudan became a member of the EAC in April 2016.
} 
in the EAC Treaty. This however does not limit its recognition as a regional economic community especially by the African Union ${ }^{20}$. Like any other organization, the EAC outlines it's objectives and principles according to article 5 and article 6 of the EAC Treaty respectively by which it operates.

The main objective of the EAC as an economic bloc is "to develop policies and programs aimed at widening and deepening cooperation among the Partner States in political, economic, social and cultural fields, research and technology, defence, security and legal and judicial affairs, for their mutual benefit". Other regional economic organizations like the ECOWAS share a similar objective. As an international organization, the EAC observes fundamental principles which are not only in line with the EAC Treaty but also compatible with universally acceptable principles whereby the member states strive to adhere to the principles of democracy, the rule of law, accountability, transparency, social justice, equal opportunities, gender equality, as well as endeavor to recognize, promote and protect human and people's rights in accordance with the provisions of the African Charter on Human and Peoples' Rights $^{21}$.

For the concrete realization and practical achievements of its goals and objectives the EAC outlines operational principles in accordance with the treaty. The operational principle of the "provision by the Partner States of an adequate and appropriate enabling environment, such as conducive policies and basic infrastructure" and also "the establishment of an export oriented economy for the Partner States in which there shall be free movement of goods, persons, labour, services, capital, information and technology" have been well implemented. Infrastructure has been a key component in enabling regional integration due to its importance in facilitating various activities including agriculture, trade, tourism and promoting free movement of persons and goods. The EAC partner states have signed agreements to this effect. One of the agreements includes the decision by the EAC Partner states to impose zero duty on goods and services among themselves. The founding partner states of the EAC jointly signed the protocol for the establishment of the EAC Customs Union (hereinafter EAC customs union protocol) in 2004 which entered into force in 2005.

This protocol is considered the first of the four main pillars of the EAC because it marked the establishment of a customs union which was to cater for the key activities in trade within the region. The EAC customs union protocol was established in accordance with article 75 of the EAC Treaty and more precisely was established

\footnotetext{
${ }^{20}$ The AU recognises eight RECs, the: Arab Maghreb Union (UMA), Common Market for Eastern and Southern Africa (COMESA), Community of Sahel-Saharan States (CEN-SAD), East African Community (EAC), Economic Community of Central African States (ECCAS), Economic Community of West African States (ECOWAS), Intergovernmental Authority on Development (IGAD), Southern African Development Community (SADC). See URL: www.http://au.int/en/ organs/rec (last visited 26 Nov 2018).
}

${ }^{21}$ EAC Treaty. Article 6(d). 
to provide for several key areas in trade which are vital for the EAC integration process including the elimination of internal tariffs and other charges of equivalent effect, the elimination of non-tariff barriers, and hence the establishment of a common external tariff. The protocol also provides for security and other restrictions to trade among others as listed in article 2 (5) of this protocol. All the other member states that joined the EAC Community afterwards, ratified the EAC Customs Union protocol as a prerequisite for joining the bloc. The second most important document and also milestone for the EAC Community is the Protocol on the establishment of the East African Community Common Market (hereinafter EAC Common market protocol). The protocol was signed by the five member states on the $20^{\text {th }}$ November 2009 in Arusha Tanzania and came into force on $1^{\text {st }}$ July 2010 after ratification by the respective member states. This is one of the Key documents of the community whose provisions are set pursuant to articles 76 and 104 of the EAC Treaty. This is the document that established a common market making it a second milestone for the East African Community integration process.

In accordance with article 4 Part $\mathrm{c}$, the EAC common market Protocol provides for the free movement of goods. Further, other vital components for effective regional integration provided for by the said protocol include free movement of persons and labour ${ }^{22}$, rights of establishment and residence ${ }^{23}$, free movement of services $^{24}$ and free movement of capital ${ }^{25}$. With a customs union and a common market in place, the EAC not only saw new members join the bloc but also embarked on initiating the third pillar of establishing a monetary union. This milestone became a reality when the five partner states signed the East African Monetary Union protocol (hereinafter EAMU protocol) on $30^{\text {th }}$ November 2013. The unique attribute of the EAMU Protocol is that a ten year time frame from the date of its establishment was created to allow partner states to "progressively converge their currencies into a single currency in the community.

The main aim of the EAMU protocol is to eventually harmonise monetary and fiscal policies, financial accounting and reporting procedures all towards establishing a harmonised East African Central bank. The fourth major pillar of the EAC is the ultimate goal of forming a political federation which is provided for under article 5(2) of the EAC Treaty. It is important to note that the EAC had been working toward becom

\footnotetext{
22 The EAC Common market protocol Article 5 (d).

${ }^{23}$ Ibid. Article 6 (e).

${ }^{24}$ Ibid. Article 7 (f).

25 Ibid. Article 8 (g).
} 
ing a political federation since it's re-establishment in $2000^{26}$. As the process of the EAC integration is ongoing, the current six partner states agreed to adopt the political confederation to act as a transitional model of the Political federation on $20^{\text {th }}$ May 2017. Somali application to join the block is yet to be considered. There has been notable progress in adhering to the principles of the Treaty in the period between the reestablishment of the EAC to date. Each of the member states recognize their individual role in meeting the Millennium Development Goals and albeit facing serious challenges, The East African partner states have developed policies, formulated and implemented programs geared towards overcoming these challenges at a regional level including achievement, reaffirmation and renewal of commitment, poverty eradication, Promoting and improving Education, Infrastructure, Health and sustainable development, Agriculture and food security, Renewable energy technologies, water resources management, Debt cancellation, Terrorism, Conflicts and Refugees, disaster management and protection of human rights (Abashidze, Koneva, Solntsev, 2016:35-38).

\section{THE STRUCTURE OF THE EAC}

In accordance with article 9(1) of the EAC Treaty, there are hereby established as organs of the Community: (a) the Summit; (b) the Council; (c) the Coordination Committee; (d) Sectoral Committees; (e) the East African Court of Justice; (f) the East African Legislative Assembly; (g) the Secretariat; and (h) such other organs as may be established by the Summit. Further article 9(4) provides that "the organs and institutions of the Community shall perform the functions, and act within the limits of the powers conferred upon them by or under this Treaty". The Summit comprises heads of government of the Partner States. The Summit main function is to give general direction towards the realization of the goals of the Community $^{27}$. Apart from issuing directives concerning the progress of the goals set

\footnotetext{
${ }^{26}$ Though the process has been slow, the EAC Heads of State resolved at a Special Summit held in Nairobi on 27-29 August 2004 to examine ways and means of deepening and accelerating the process through a fast-track Mechanism. The Summit set up a Committee to Fast-Track the EAC Political Federation, dubbed the Wako Committee, to carry out wide consultations and finalise the work on the Political Federation. The Committee presented its report to the Summit on 29 November 2004. As a result of the consultative process, the office of Deputy Secretary-General responsible for Political Federation was established in 2006 to coordinate this process. Since 2004, the EAC has been putting in place initiatives to fast-track political integration. Summit directives were given and national consultations with stakeholders between 2006 and 2008 as well as various studies were undertaken to examine, facilitate and fast-track the process. In the consultations, it became clear that the East African citizens want to be adequately engaged and to have a say in the decisions and policies pursued by the East African Community. Available at URL https://www.eac.int/political-federation.

${ }^{27}$ EAC Treaty. Chapter 4.
} 
out by the community, during the annual heads of states meetings as provided for by the treaty, the summit also reviews reports from the council for consideration.

The summit also handles membership issues such as admitting foreign countries into the Community ${ }^{28}$ and in accordance with Articles 143,146 and 147, the summit is responsible for handling sanctions on, and suspension and expulsion of errant Partner States. Additionally, the utter most important function of the Summit in this time of globalization is without a shadow of doubt, to oversee the state of peace and security that will promote good governance within the Community ${ }^{29}$. The Summit, which decides by consensus, may delegate the exercise of its functions to the Council or the Secretary General, except when making decisions to appoint judges to the EAC Court of Justice and the assent to bills. The Council of Ministers which is the main decision making body comprising ministers of the partner states responsible for regional co-operation and such other Ministers as the Partner States may determine ${ }^{30}$. The Council, which also decides by consensus, is the policy organ of the Community and is empowered inter alia to make policy decisions, initiate and submit Bills to the Assembly, give directions to the Partners States and other EAC institutions/organs with the exception of the Summit, the Court and the Assembly, and to adopt (legally binding) regulations, directives and decisions.

The Co-ordinating Committee is made up of permanent secretaries responsible for regional co-operation. It is responsible for the activities of the sectoral committees and reports to the Council ${ }^{31}$. The Sectoral Committees are established by the Council on recommendation of the respective Co-ordinating Committees. They develop and monitor the implementation of the programs of the EAC ${ }^{32}$. The East African Court of Justice functions and fulfils its obligations under the Treaty. The court took office on 30 November 2001, following the official opening of the summit on the inauguration of judges. According to article 42 of the EAC Treaty on the rules of the Court and Oaths of Office, "the Court shall make rules of the Court which shall, subject to the provisions of this Treaty, regulate the detailed conduct of the business of the Court. The Secretary General shall prepare the oath and declarations that the Judges and the Registrar of the Court shall take before the Summit upon their appointment or make upon entering into their duties". The court provides oversight, enforcement and dispute resolution. This characteristic is inherent in all international courts of integration organizations (Njenga 2015b).

Established under Article 9 of the EAC Treaty, The East African Legislative Assembly (hereinafter EALA) is the Legislative Organ of the Community and has a cardinal function to further EAC objectives, through its Legislative, Representative

\footnotetext{
${ }^{28}$ EAC Treaty. Article 3 (5).

${ }^{29}$ Ibid. Article 11(3).

${ }^{30}$ Ibid. Article 13.

${ }^{31}$ Ibid. Article 17.

${ }^{32}$ Ibid. Article 18 (a-e).
} 
and Oversight mandate. According to the EAC Treaty, The Assembly has a membership comprising of 45 elected Members (nine from each Partner State), and 7 exofficio Members consisting of the Minister or Cabinet Secretary responsible for EAC Affairs from each Partner State, the Secretary-General and the Counsel to the Community totaling 52 Members. The Assembly draws the authority to establish its Standing Committees from its Rules of Procedure. It currently has 6 Standing Committees to execute its mandate. The Secretariat is the executive organ of the Community which is headed by the Secretary General and his deputies. There is also a counsel to the community and "other offices as may be deemed necessary by the council" 33 . The Secretary General is mandated by the EAC Treaty to "act on behalf of the Secretariat where he or she thinks it appropriate" ${ }^{\text {"34 }}$.The Secretariat has a wide range of functions listed under article 71 of the EAC treaty including initiating, receiving and submitting recommendations to the Council, and working closely with the EALA by forwarding of Bills through the Co -ordination Committee; The Secretariat carries out the initiation of studies and research related to, and the implementation of, programs for the most appropriate, expeditious and efficient ways of achieving the objectives of the Community as well as the strategic planning, management and monitoring of programs for the development of the Community.

Evidently, there is a unique mechanism of how the EAC organs function. For example, the Treaty provides that, whereas there are limitations ${ }^{35}$, it is permissible when need arises ${ }^{36}$, for the Summit to delegate any of its functions or confer even legislative powers through an Act of the Community, to a member of the Summit, to the council or to the Secretary General. The Summit ensures that "all rules and orders made by it under this Treaty" shall not only enter into force on the date of publication but also officially appear in the gazette. These decision and Acts of the summit, according to the treaty, are considered official only under the signature of the Secretary General or of "any officer in the service of the community authorized in that behalf by the summit".

\section{CONCLUSION}

Despite striving for strengthening of regional economic communities within the continent, the success in achieving its aims has been slow and somewhat uninspiring. On the other hand one cannot ignore the fact that the intra-Africa trade is not small compared to what should be expected. Various arguments are suggested as

\footnotetext{
${ }^{33}$ EAC Treaty article 66.

${ }^{34}$ Ibid.

${ }^{35}$ See article 11(9) (a) the giving of general directions and impetus (b) the appointment of judges to the East African Court of Justice (c) the admission of new Members and granting of observer Status to foreign countries; and (d) assent to bills.

${ }^{36}$ See article 4(1) The Summit delegation of Powers and functions Act 2007.
} 
causes for the lack of progress in regional integration efforts in Africa. Chief among them is laxity of state partners to surrender sovereignty of macroeconomic policy making to a centralized regional authority as well as the reluctance of individual member states to severe and discontinue existing economic ties with non-members (Johnson, 1995: 1-26).

Since its establishment, the East African Community has created a ripple effect on a trending demand for deeper understanding of the significance of regional integration and the role played by their subsequent organs specially the sub regional courts in East Africa in particular, within the context of International law, its principals and objectives. Even as experts argue that the lack of commitment in the continent towards strengthening international cooperation frameworks and also the reluctance to be intent on integration stands as a stumbling block as seen in an article published by Veit Bachmann and James D Sidaway, African regional integration and European involvement: external agents in the East African Community, ${ }^{37}$ a conclusive report ${ }^{38}$ reflects that the EAC has made a milestone in achieving most of their goals set in The Treaty on widening and deepening the integration process among the six partner states.

Remarkable progress has been made in as far as free movement of people is concerned. Just like in the ECOWAS, the EAC is one of the Communities whose member states and citizens of the region enjoy free movement within the region. The EAC passport is operational and allows multiple entries to citizens from Partner States to travel freely within the EAC region for a period of six months. A great influence of the judges of the EACJ in its active role to strengthen regional integration is inclusive participation of activists, lawyers, civil societies and government agencies towards promoting adherence to key internationally and legally binding documents. In the past, these effective changes in the EACJ would not have been possible as the effects of colonialism still had a tight grip on the judiciary system in each of the three East African States - Kenya, Uganda and Tanzania which meant that authority was held exclusively by the colonialists. Although a common market had been top on the agenda right after the three initial member states had gained independence, the EAC commenced the implementation of the Common Market in July, $2010^{39}$. This brought about great developments in the economic sphere including the reduction of national trade barriers, free movement of stocks which is key to effective integration. Other major achievements ${ }^{40}$ can be noted in the political and security sphere for example the establishment of joint military exercises by the Partner States Defense Forces.

The EAC has proved to have strong enough legal background to stand the test of time in the process of integration in the region; however the underlying challenge

\footnotetext{
${ }^{37}$ South African Geographical Journal, 91 (2010) 1. P. 1-6.

${ }^{38}$ The EAC Facts and Figures Report. 2014.

${ }^{39}$ Established on the basis of Article 5 (2) of the EAC Treaty.

${ }^{40}$ www.meac.go.ke/index.php/2014-08-29-10-48-01/10/eac-achievement (Accessed 01.02.2016).
} 
remains on how to strengthen its organs by demonstrating assertiveness in tackling difficult and sensitive issues and effectively implementing agreements especially at regional level. Another stumbling block towards strengthening the legal status is political manipulation by the partner states purely out of selfish interest. Through resilience, the EACJ has proved its stamina in some sensitive case laws. One of these cases is Burundi journalist Union v Attorney General of Burundi where EACJ held that the media law of Burundi had violated the East African Community Treaty by prohibiting journalists "from reporting on certain topics" as well as requiring them to "reveal their sources to the government". The limitations of the EACJ only to declare infringements, order injunctive relief and impose costs on international human rights law may appear insignificant in relation to the speed at which the integration process is happening. Nonetheless, though 'insignificant', the reasoning and analysis in some human rights case laws in East Africa brought before the EACJ improved the enforcement of EAC integration projects founding legal instruments. In this regard, the process of regional integration in the east African Community can be said to promote and uphold one of the most important human right-the right to freedom of movement, without which regional integration is impossible (Helfer, 2015).

Finally, The EAC, unlike any other REC in the continent has promoted many other fundamental rights and freedoms including observing principles of nondiscrimination of nationals of partner states based on their nationality and according them equal treatment. This has been effective through East African Common Market Protocol which additionally facilitates solidarity between member states by eliminating barriers to trade. Further, under the Common Market Protocol, the free movement of goods and services is to be implemented and although the member states adhere to guarantee protection of other members citizens within their borders "citizens are not exempt from prosecution for crimes committed and Member States may impose limitations for public policy, security, or public health purpose in accordance with their national laws with the observance of applicable principles of international law (Thuo, 2011:188-190).

The top priority by EAC member states should be to create "enabling environments" (Social, political and economical) and "set performance standards against which governments and other actors can be held accountable". Ochanda, Wakinya, Odipo 2013: 47-73).

\section{REFERENCES}

Whitaker. P 1964. Political Theory and East African Problems // London Oxford University Press, 1964, p. 84.

Possi. A 2013 The East African Court of Justice: Towards Effective Protection of. Human Rights in the East African Community // Max Planck Year book of United Nations Law, volume 17,2013, pp. 173-195.

Njenga L.N. (2015a) Regional Integration in Africa: The East African Community in the context of international relations // Материалы XIII Всероссийской школы молодых африка- 
нистов. Москва, 17-18 ноября 2015 года. М: Институт Африки Российской Академи Наук, 2015. С. 64-66.

Njenga. L. N. (2015b) Activities of the Court of the East African Community, Eurasian Law Journal, №12 (91), pp. 55-57.

Stefan Reith, Ritz Boltz. 2011.The East African Community: Regional and Integration between aspiration and reality // KAS International reports 9.10.2011.

Sebalu, P.1972 The East African Community. Journal of African Law. 1972 Vol. 16, No. 3, pp. 345-363.

Abashidze A, Koneva A, Soltsev A. (2016). Africa in the Shadow of Tomorrow // Kazan Journal of International Law and International Relations. 2016, pp. 35-38.

Johnson O. E.G. (1991). Economic Integration in Africa: Enhancing prospects for success // The Journal of Modern African Studies N. 29,1 (1991), pp. 1-26.

Helfer Laurence R. (2015) Sub-regional Courts in Africa: Litigating the Hybrid Right to Freedom of Movement // iCourts Working Paper Series, No. 32, 2015.

Gathii James Thuo (2011). African Regional Trade Agreements as Legal Regimes // Cambridge University press 2011, pp. 188-190.

Muko Ochanda R., Kisolo Wakinya P., Omondi Odipo W. (2013). Human Rights in the Context of Deepening Integration of East African Community (EAC) // Postmodern Openings, Volume 4, Issue 2, June 2013, pp. 47-73.

\title{
Information about the author:
}

Lily N. Njenga, Postgraduate student, Department of International Law, Law Institute, RUDN University

ORCID ID: 0000-0002-5235-9598

Contact information:

e-mail: njengalily01@gmail.com

\section{For citation:}

Njenga, L.N. The legal status of the East African Community (EAC) (2018). RUDN Jurnal of Law, 22 (3), pp. 370-384. DOI: 10.22363/2313-2337-2018-22-3-370-384.

Article received August 31, 2018

Article accepted October 15, 2018

\section{ПРАВОВОЙ СТАТУС ВОСТОЧНОАФРИКАНСКОГО СООБЩЕСТВА (ВАС)}

\author{
Л. Н. Ндженга \\ Российский университет дружбы народов \\ Юридический институт \\ 117198, Москва, Россия, Миклухо-Маклая, д. 6
}

Развитие Восточноафриканского сообщества (далее - BAC) на протяжении последнего десятилетия в значительной степени напоминает историю других международных региональных организаций. Например, Европейское экономическое сообщество (далее - ЕЭС), согласно Римскому договору 1957 г. образованное для развития экономической интеграции между его госу- 
дарствами-членами, в 1993 году было включено в Европейское Сообщество, а позднее — в Европейский Союз.

В статье рассматриваются ранние этапы становления ВАС, вставшие перед ним проблемы и пути их преодоления. Также автор уделяет внимание роли, функциям и влиянию Восточноафриканского сообщества и Суда Восточноафриканского сообщества (далее - суд ВАС) в различных сферах международного права, включая защиту прав человека в Восточноафриканском регионе. В результате усиления региональной интеграции на континенте региональные экономические сообщества (далее - РЭС) стали организациями с окрепшей правовой структурой, чья успешная судебная практика в области обеспечения и защиты прав человека служит на благо не только государств-членов ВАС, но и Африканского континента в целом.

В данной статье также затрагивается вопрос о том, в какой степени ВАС действительно придерживается принципов демократии, верховенства права и социальной справедливости.

Особое внимание автор уделяет анализу различий между ВАС и другими региональными экономическими организациями континента. Рассматривая историю ВАС, в том числе процедуру его воссоздания в 2000 г., автор показывает особенности его правового статуса, а также путь к ключевой цели - созданию Африканской федерации согласно принципам Договора о ВАС, которые, в свою очередь, опираются на принципы международного права. К моменту распада ВАС в 1977 г. его основной судебный орган был переименован в Восточноафриканский Апелляционный суд, и хотя он так же прекратил свое существование. В настоящее время суд ВАС является одним из наиболее влиятельных и независимых органов Восточноафриканского сообщества. Наряду с остальными органами ВАС данный суд должен функционировать и выполнять обязанности строго в соответствии с Договором. Очевидно, что еще до получения независимости каждым из государств-членов ВАС существовала общая идея о формировании в Восточной Африке централизованной системы управления, которая включала бы все племена и культуры. Этапы ее воплощения в жизнь подробно рассматриваются в данной статье.

Ключевые слова: Суд Восточноафриканского сообщества (суд ВАС), Правовой статус, региональные экономические сообщества (РЭС), договор, распад, создание, история, интеграция

\section{Сведения об авторе:}

Ндженга Лили Нджери, аспирант кафедры международного права Юридического института Российского университета дружбы народов

ORCID ID: 0000-0002-5235-9598

Контактная информаџия:

e-mail: njengalily01@gmail.com

\section{Для цитирования:}

Ндженга Л.Н. Правовой статус Восточноафриканского сообщества (ВАС) // Вестник Российского университета дружбы народов. Серия: Юридические науки. 2018. T. 22. № 3. C. 370-384. DOI: 10.22363/2313-2337-2018-22-3-370-384.

Дата поступления в редакциию 31 августа 2018 г. Дата принятия к печати 15 октября 2018 г. 